\title{
ANÁLISE JURÍDICO-FILOSÓFICA DO SACRIFÍCIO DE ANIMAIS NÂO HUMANOS NO CANDOMBLÉ
}

\author{
Pedro Henrique Moreira da Silva ${ }^{1}$ \\ Escola Superior Dom Helder Câmara (ESDHC) \\ Artigo recebido em: 03/12/2018 \\ Artigo aceito em: 08/02/2019
}

\section{Resumo}

$\mathrm{O}$ estudo pretende suscitar a questáo do conflito entre liberdade religiosa e direito animal, no que tange ao sacrifício de animais não humanos nos cultos de Candomblé - religião de matriz africana. Recorrendo ao método hipotético-dedutivo e à pesquisa bibliográfica, buscar-se-á uma análise da temática pelas perspectivas do Direito e da Filosofia, sem furtar-se da consideraçáo dos aspectos éticos, sociais, étnicos, teológicos e do ordenamento jurídico internacional. Isto é, ao mesmo tempo em que os animais não humanos serão apresentados nas perspectivas dos princípios da dignidade - que decorrem das noçôes de "outridade" -, também serão consideradas as dimensóes da liberdade religiosa e da necessidade de coesão sociocultural para fortalecimento do debate. Nesse sentido, justifica-se a pesquisa pela complexidade do tema, pela necessidade de coerência sócio-política na discussão e em razão do futuro julgamento da pauta pelo Supremo Tribunal Federal - que mais que recorrer às jurisprudências estrangeiras, também deve se preocupar com a as dimensóes filosóficas e teológicas que envolvem a causa religiosa e animal.

Palavras-chave: liberdade religiosa; Direito Animal; Candomblé; Religião; Direitos Fundamentais.

1 Mestrando em Direito Ambiental e Desenvolvimento Sustentável pela ESDHC. Bacharel em Direito pela ESDHC. Bacharelando em Letras pela Universidade Federal de Minas Gerais (UFMG). Advogado. ORCID: https://orcid. org/0000-0002-8217-2169 / e-mail: pedroadvdireito@gmail.com 


\section{JURIDIC-PHILOSOPHICAL ANALYSIS OF THE SACRIFICE OF ANIMALS IN THE CANDOMBLÉ}

\section{Abstract}

The study intends to raise the issue of the conflict between religious freedom and animal rights, regarding the sacrifice of animals in the cult of Candomble - religion of african origin. Using the hypothetical-deductive method and the bibliographical research, it will seek an analysis of the thematic by the perspectives of Law and Philosophy, without evading the consideration of ethical, social, ethnic, theological and international legal order. That is, at the same time that animals will be presented in the perspective of the principles of dignity - which stem from the notions of otherness - the dimensions of religious freedom and the need for so- cio-cultural cohesion to strengthen the debate will also be considered. In this sense, the research is justified by the complexity of the topic, by the need for socio-political coherence in the discussion and due to the future judgment of the agenda by the Supreme Court - that rather than resort to foreign jurisprudence, must also be concerned with the philosophical and theological dimensions that involve the religious and animal cause.

Keywords: religious freedom; Animal Rights; Candomblé; Religion; Fundamental rights.

\section{Introdução}

A liberdade religiosa consagra-se na Declaração Universal dos Direitos Humanos e na Constituição da República Federativa do Brasil como direito fundamental - essencial para o alcance da dignidade humana. Nesse sentido, o Estado não pode impor ou vetar religióes e mais, deve tratar de viabilizar o exercício das crenças - seja no que tange aos rituais, liturgias e demais organizaçôes.

Referido direito ganha importante destaque no ordenamento pátrio, tendo em vista a constituição religiosa do Brasil. Isto é, com o processo de colonização e as particularidades que lhe são próprias, o desenvolvimento social no país foi consideravelmente miscigenado e plural - resultando na absorção de identidades religiosas já consolidadas e na produção de novas identidades e crenças. É o que se verifica, por exemplo, nos casos da Umbanda e do Candomblé que, por meio do esforço dos africanos para conservarem a tradição originária em face da imposição da doutrina católica no império, se sobressaíram como religiôes sólidas e que agregam inúmeros crentes. 
Algumas dessas religiốes - como o Candomblé - distanciam-se da ética cristã hegemônica e do maniqueísmo místico, de forma que são cultuadas entidades que, não raras vezes, exigem sacrifícios como forma de romperem o véu que separa as dimensóes humanas das dimensóes espirituais. Assim, o abate de animais não humanos é uma questão tradicional - além de requisito para a própria viabilidade dos cultos - que tem gerado controvérsias quando contraposto ao Direito animal.

Isso porque, apesar da sociedade brasileira ser majoritariamente consumidora de carne (RIBEIRO; CORÇÃO, 2013), conserva-se a concepção de que os animais não humanos são constrangidos ao sofrimento durante os rituais do Candomblé, o que seria suficiente para vetar a prática. Não obstante, considerando-se o status do direito de liberdade religiosa e o racismo institucionalizado - que já se delineia incontroverso -, faz-se necessária uma discussão mais profunda acerca da problematização do sacrifício nas religiōes de matriz africana.

Nesse sentido, a pesquisa propóe-se - por meio do método hipotético-dedutivo e do estudo bibliográfico - a invocar as dimensôes jurídicas e filosóficas que viabilizem uma análise dual da questáo suscitada. Assim, pela delicadeza e pertinência do debate, serão considerados os aspectos sociais, éticos, políticos, jurídicos, teológicos e filosóficos que envolvem o sacrifício dos animais não humanos no Candomblé para que, ao fim, seja formulada uma conclusão a respeito da prática - ou seja, responder-se-á se o abate desses animais é legítimo na perspectiva jurídico-filosófica delineada.

\section{Liberdade religiosa no Brasil}

O Constituinte brasileiro, ao redigir a Constituição da República Federativa do Brasil, de 1988, tratou de estender um farto rol de direitos fundamentais - com significativa concentração no artigo $5^{\circ}$. Para o que pretende a pesquisa, vale invocar por primeiro o inciso VI do artigo supra, que versa acerca da inviolabilidade da liberdade de consciência e de crença, "sendo assegurado o livre exercício dos cultos religiosos e garantida, na forma da lei, a proteçáo aos locais de culto e às suas liturgias" (BRASIL, 1988).

As raízes históricas da liberdade religiosa são marcadas pelas reformas de Lutero e Calvino, enquanto experiências contra hegemônicas. Isto é, as garantias de ruptura ocidental com a Igreja Católica Apostólica Romana demandaram um aparato legislativo para supressão do poder religioso - possibilitando crenças alheias aos padróes culturais europeus da alta Idade Média (MARMELSTEIN, 2009).

Referido direito decorre dos princípios gerais de liberdade e igualdade, na medida em que assegura que o Estado não discrimine seus cidadãos, ao contrário, que os trate como iguais - independentemente dos credos e tendências culturais 
(CANOTILHO, 2002). Trata-se, portanto, de direito fundamental de primeira dimensão, que surge para proteger o indivíduo de possíveis arbitrariedades do Estado (PAES, 2013).

Essa liberdade implica na impossibilidade de o Estado impor determinada religião a qualquer indivíduo e mais, define também o dever do Estado na garantia e viabilização das religióes (MIRANDA, 2000). Assim, pode-se dizer que a liberdade religiosa é gênero que abarca a liberdade de crença, de culto e a liberdade de organização religiosa (MORAIS, 2011).

José Afonso da Silva (1989) leciona que a liberdade de crença se relaciona à possibilidade de crer em determinadas entidades e a liberdade de organização religiosa com a possibilidade de criarem-se estabelecimentos e organizaçóes. A liberdade de culto, por sua vez, diz respeito à possibilidade da prática de rituais, cantos e demais liturgias (COIMBRA; KUO, 2009).

A liberdade religiosa, enquanto gênero, para além da positivação na Constituição Federal brasileira, decorre da liberdade em sentido amplo e da liberdade de pensamento consagradas na Declaração Universal dos Direitos Humanos que dispóe em seu artigo 18, in verbis:

Toda pessoa tem direito à liberdade de pensamento, consciência e religiáo; este direito inclui a liberdade de mudar de religiâo ou crença e a liberdade de manifestar essa religião ou crença, pelo ensino, pela prática, pelo culto e pela observância, isolada ou coletivamente, em público ou em particular (ONU, 1948).

O que pode ser concluído, portanto, é que o direito de professar crenças individuais, particulares e múltiplas, praticando os rituais que elas demandem, é uma garantia humana - requisito para a dignidade. Importa dizer, todavia, que esse direito não pode ser tutelado no caso de ofender outras disposiçóes jurídicas e principiológicas. Isto é, não se torna defensável o sacrifício humano em nome da liberdade de pensamento - por exemplo -, tendo em vista que alguns interesses e direitos mais gerais não podem ser ofendidos - como é o caso da vida.

É nesse contexto que surgem as discussôes que contrapóe a liberdade religiosa com o direito à vida e dignidade dos animais não humanos, na medida em que as religióes de matriz africana - principalmente - se apropriam dessas "bestas", abatendo-as durante seus cultos. Assim, tendo em vista a natureza do conflito de interesses, deve-se recorrer à hermenêutica para uma solução satisfatória do entrave - sem que sejam ignorados os valores socioculturais envolvidos na questáo, que é abstrata, genérica e complexa (PIRES, 2012).

Conforme explana Teresinha Inês Teles Pires (2012), o positivismo e as 
interpretaçôes lógico-semânticas são insuficientes para a solução desses conflitos, em razão de sua baixa praticidade. Assim, no que diz respeito à questáo do direito animal em face do sacrifício nas religiōes de matriz africana, há que se recorrer ao método hermenêutico concretizador - que possibilita a consideração das subjetividades da causa e do contexto sociopolítico (PIRES, 2012).

O debate acerca da questão deve ser descentralizado, recorrendo-se aos diferentes âmbitos da sociedade - direito, ciência, teologia, sociologia, por exemplo. Ademais, também deve ser considerada a participação da comunidade e das entidades representativas dos setores sociais, de forma que as instituiçôes sejam aprimoradas e fortalecido o paradigma democrático (UNGER, 2004).

Por esse caminho - considerando-se a densidade do tema -, contorna-se a possibilidade de esvaziamento democrático (HÄBERLE, 2002) e as chances de "conluio entre poder político e vantagem econômica" (UNGER, 2004, p. 36) sobre os interesses sociais, sobretudo por se tratar de direitos de ordem humana, indispensáveis à manutenção da condição de dignidade. É justamente por meio desta perspectiva que procura a pesquisa uma conclusão a respeito da questão do sacrifício de animais não humanos nos cultos de Candomblé - o que demanda, por primeiro, uma apresentação acerca das religiōes derivadas da cultura mística do continente africano.

\section{O Candomblé e a questáo do abate de animais náo humanos}

As religiōes de matriz africana organizam-se em linhas patrilineares e matrilineares, com a característica geral de culto aos antepassados e divindades superiores - quais sejam, orixás, voduns e inquices. Essas religióes são marcadas pelos aspectos dos ensinamentos principiológicos (com forte influência da cultura oral) e pelos aspectos de religiosidade concreta, ou seja, a exteriorização da fé em comportamentos e cultos (FERREIRA; GONÇALVES, 2008).

Em geral, as crenças perpetuadas ao longo dos séculos têm como ponto de partida o mito iorubá a respeito da criação do mundo: Olorum, o deus criador, fez o mundo e confiou-o a Odudua. A ela entregou um lenço cheio de terra e uma galinha, para que derramasse aquela terra por sobre as águas e fizesse o solo habitável. Esta história, note-se, preocupa-se mais em informar a ordem das coisas do que em fornecer detalhes. Estes últimos são dados em mitos secundários, que apontam para a ascensão de divindades (FERREIRA; GONÇALVES, 2008).

Ainda segundo a crença iorubá, os primeiros humanos mantinham uma relação comum na terra, mas possuíam capacidades especiais - o que os faziam 
melhores que os demais seres que povoavam o mundo. "Dentre essas habilidades, estavam: os segredos da mata e do ferro, o poder sobre os ventos e tempestades, os conhecimentos sobre a caça, o poder de cura de doenças e muitos outros" (BARBOSA, 2012, p. 13). Assim, quando morreram, foram renascidos na forma dos orixás.

A partir desse centro mítico, a cultura iorubá trata de afirmar que os homens são descendentes dos orixás, o que confere aos humanos origens plurais - ao contrário da lógica criacionista do cristianismo. O que se pode dizer é que "os humanos são apenas cópias esmaecidas dos orixás dos quais descendem” (PRANDI, 2001, p. 4).

Importa dizer ainda que as culturas religiosas africanas apontam para a existência de dois planos: o Orum e o Aiye. No primeiro, vive Olorum, o ser supremo, que habita uma dimensão não palpável. Os humanos, por sua vez, encontram-se no Aiye, onde é permitida a entrada dos orixás. Para tanto, é necessário que seja realizado um ritual de invocação, cujo encantamento é suficientemente poderoso para romper o véu do sistema Orum-Aiye - assim, são promovidos cultos, oferendas e sacrifícios, que podem ser entendidos como os instrumentos que viabilizam a comunicação e contato entre homens e divindades (FERREIRA; GONÇALVES, 2008).

O culto de Candomblé é, portanto, uma maneira de contornar a divisão entre as dimensóes espirituais e carnais, fazendo reinar o equilíbrio dos mundos. $\mathrm{O}$ anseio dos rituais é garantir a unidade primitiva entre Orum e Aiye, "compreendida como uma situaçấo de total harmonia e felicidade; por isso mesmo, ela é sempre novamente buscada" (BERKENBROCK, 2007, p. 18).

Assim, o papel das religióes africanas assume a importância de referência de identidade. No Brasil, o Candomblé assume a imagem e a força da resistência contra as tentativas de proibição de cultos não cristão. Dessa forma, muito do que foi criado com os iorubás foi recriado a partir da associação com as imagens sacras cristãs (D’ADESKY, 2001). A própria construção dos terreiros é uma tentativa de promover uma materialização da África para invocação das divindades ali nascidas (FERREIRA; GONÇALVES, 2008)

O Candomblé, assim como a maioria das religiōes de matriz africana, é marcado por transes e cultos a espíritos - que se viabilizam pelo sacrifício animal. O sacrificium - "tornar sagrado" - pode ser definido como uma oferta para outro plano, como referência a renúncia de um bem ou ser (GROTTANELLI, 2008).

Essa prática pode ocorrer em três esferas e modalidades distintas, quais sejam: a) oferenda das primícias, que se funda na percepção de que os bens ambientais pertencem a outro plano, de forma que o consumo e abate desses elementos está 
condicionado à restituição de parte do que o homem toma para si; b) sacrifício-doação, que se funda na percepçáo que o homem é senhor dos bens ambientais e, buscando o agrado dos orixás, oferece-os a seus superiores, renunciando a estes bens; c) comunhão, em que o "ser extra-humano é comensal do homem no ato de consumir a vítima ou a comunhão se obtém mediante a absorção do próprio ser extra-humano" (ROCHA, 2015, p. 46).

Todavia, por se tratar de uma manifestação religiosa sem a preocupação ética do dualismo entre bem e mal, há uma tendência de discriminação do Candomblé. Inclusive, importa dizer que essa marginalização também se materializa em razão da cultura racista e de inferiorização e depreciação dos modos africanos (NASCIMENTO, 2010).

Assim, tendo em vista o contexto colonial - cujo legado paradigmático se estende até a atualidade -, verifica-se que o questionamento acerca da legitimidade do sacrifício de animais não humanos no Candomblé pode ser entendido como parte de um movimento sistêmico de supressão da cultura negra. Como outrora a Igreja Católica Apostólica Romana no Brasil entendeu os batuques e transes africanos como a manifestação do mal (NASCIMENTO, 2010), hoje a comunidade em geral tende a projetar essa mesma percepção quando das discussões acerca da temática do sacrifício animal nos cultos realizados dentro de terreiros. Trata-se do paradoxo da sociedade ocidental que se escandaliza com o abate religioso de "bestas" e cultiva uma significativa cultura de consumo de carne (RIBEIRO; CORÇÃO, 2013).

Considerando-se que a doutrina básica do Candomblé ensina que a aproximação entre o Orum e o Aiye é possível táo somente por meio do sacrifício animal, restringir o abate desses seres significa restringir a própria realizaçáo dos cultos, na medida em que o instrumento de comunicação entre o profano e o divino estaria vetado. Nesse tocante, vale retomar as reflexôes acerca da garantia constitucional de manifestação religiosa - cujo vilipendio implica na violação de Direito Humano inegociável.

Ademais, não há que se relevar a informação de que os próprios praticantes do Candomblé se incumbem da tarefa de induzir o animal não humano a um estado que atenua seu sofrimento - o que se faz por meio da sedação alcoólica, por exemplo. Isso ocorre tendo em vista que o sacrifício não é uma prática sádica e conectada à magia negra. Ao contrário, trata-se de um ritual que carece de respeito e cuidado, já que o abate viabiliza a recepção de entes sagrados dentro do terreiro.

Os contextos da discussão supra foram invocados em uma debate jurídico-político no estado brasileiro do Rio Grande do Sul. A deputada Regina Becker, do PDT, propôs projeto de lei para vetar a utilização de animais nos cultos 
de Candomblé, sob a alegação de ofensa ao Código Estadual de Proteção aos Animais. Segundo a parlamentar, o abate de animais é uma questão de saúde pública, na medida em que a principal consequência da prática é a putrefação das "bestas" em locais públicos, o que termina por constranger os cidadãos que não compactuam com a prática (ROCHA, 2015).

A questão foi suscitada no Supremo Tribunal Federal, por meio do Recurso Extraordinário no 494.601, com o posicionamento do Relator Ministro Marco Aurélio Mello no sentido de que o sacrifício de animais não humanos deve ser permitido em todas as religiốes, sob pena de se incorrer na violação do direito constitucional de liberdade de crença. Não obstante, esse sacrifício ficaria condicionado à vedação da tortura e ao consumo posterior da carne (STF, 2018a).

Para chegar a referido posicionamento, o Ministro Relator utilizou-se de decisôes de Cortes Constitucionais de outros países que outrora foram mobilizadas em relação a temas similares. O primeiro caso invocado é o Chảare Shalom Ve Tsedek vs. France, do ano 2000, em que ficou decidido pelo Tribunal Europeu de Direitos do Homem que o artigo $9^{\circ}$ da Convenção Europeia dos Direitos do Homem contempla o abate religioso como direito inquestionável. Em sentido similar também decidiu o Tribunal Federal da Alemanha, em 2002, suscitando que a permissão para o sacrifício de animais em cultos depende tão somente da declaração da convicção religiosa (STF, 2018a)

Os Tribunais Constitucionais da Áustria, Estados Unidos da América e Israel também adotaram posicionamentos semelhantes. Assim, o abate de animais é considerado como parte integrante do livre exercício de religião, de forma que é inconstitucional qualquer lei que proíba o sacrifício destas "bestas" (STF, 2018a) A tendência jurídica, portanto, é que o abate animal seja relativizado para garantia dos Direitos Humanos - sobretudo aqueles relacionados à cultura e à religiáo.

No Brasil, a discussão no Supremo Tribunal Federal não foi encerrada, tendo em consideração o pedido de vistas do Ministro Alexandre de Morais, conforme consta nos autos no RExt 494.601. Assim, mais que promover uma cópia das tendências mundiais acerca da temática, propõe a pesquisa ser necessário ao STF aprofundar uma discussão filosófica que considere, para além dos Direitos Humanos, também as questóes de alteridade e outridade e os paradigmas que se conectam à sustentabilidade e respeito com os animais não humanos, conforme apresentar-se-á. 


\section{Percepçóes filosóficas acerca do sacrifício de animais náo humanos em cultos religiosos}

A tratativa animal, para além das construçôes histórico-sociais, está diretamente ligada às percepçóes acerca das capacidades racionais humanas e da não racionalidade das "bestas". Trata-se de uma dinâmica ocidental que, se não conectada com a realização de cultos e expressão cultural, está atrelada com o próprio consumo de carne.

No Oriente, por outro lado, a ética com os animais é delineada de forma distinta, com traços de uma tratativa pautada no respeito à vida humana e não humana. Nos mosteiros na Ásia, por exemplo, o cozimento de qualquer carne animal não é aceito, tendo em vista que demanda a retirada da vida de outros seres (ROCHA; MONTEIRO, 2017).

Essa conduta, note-se, é desvinculada da lógica das religióes de matriz africana ou das construçóes judaico-cristâs. O hinduísmo, predominante mais a oriente, toma por sacras as coisas que existem na natureza, sem juízo acerca das capacidades racionais ou cognitivas. Trata-se de uma percepção mais enrijecida no que tange a ética ambiental. Isto é, "sobre a base democrática da filosofia oriental, é imperdoável que o homem se sirva do animal para sua alimentação, matando-o, uma vez que vigora estreita afinidade entre homem e animal; seria uma espécie de canibalismo" (RHODEN, 1982, p. 16).

O cristianismo, por sua vez, possibilita uma interpretação mais aberta e menos protecionista da condição animal. O homem, por ser imagem e semelhança do Criador, pode exercer controle sobre as outras coisas - a posição equiparável à divindade confere ao ser humano o status de senhor. Cabe-lhe, portanto, o domínio sobre os peixes que habitam o mar, as aves que povoam os céus e sobre as bestas que pisam sobre a terra.

Essa corrente interpretativa acaba sendo avalizada pelo pensamento cartesiano, na medida em que o res cogitans é elencado a posto superior ao res extensae: o homem como amo da natureza. Assim, afasta-se a culpa pelo abatimento de animais não humanos - sendo condicionado o abate a questóes alimentícias, na maioria das vezes.

Isso significa dizer que, pela lógica ocidental - sobretudo aquela proveniente do pensamento cristão -, a separação entre animal humano e animal não humano se dá pelo simples desenvolvimento de um sistema nervoso capaz de conferir consciência e razão. Tudo o que foge ao referido padrão é passível de objetificação, sem a consideração das capacidades de senciência que conservam as "bestas".

A respeito do tema, qual seja a capacidade de sentir, Darwin confirmaria que 
os animais não humanos são capazes de sentir dor, alegria, ciúme e respondem a estímulos relacionados ao prazer. Inclusive, essa capacidade de sentir provoca alterações fisiológicas, alterando a pressão arterial, ritmo cardíaco e contrações musculares, tal qual ocorre com os humanos (DARWIN, 2004).

Ademais, o conhecimento darwiniano permitiu que fossem constatadas múltiplas personalidades nos animais não humanos. Assim, da mesma forma que existem homens ranzinzas e homens extrovertidos, também existem cavalos com as mesmas variaçôes de humor. Os animais não humanos também apresentam comportamentos altruístas, como se nota nas fêmeas primatas que adotam filhotes abandonados e nas baleias cachalotes que protegem outros animais de seus predadores (SALLES, 2017). Esse comportamento, por si só, bastaria para incluir as "bestas" no contexto moral.

Marcelo Antônio Rocha e Márcia Sales Monteiro confirmam a questão ao dissertarem que

O fato de os animais não serem autoconscientes não é condição permissiva para que as pessoas ignorem seus interesses sempre que for conveniente a elas, nem as desobriga de deveres para com os animais [...] Embora, para Singer os animais não tenham autoconsciência, isso não significa que eles devam ser excluídos da comunidade moral (ROCHA; MONTEIRO, 2017, p. 47).

Essa questão fortalecer-se-ia a partir de 1972, com a instituição do paradigma da sustentabilidade pela Convenção de Estocolmo - a ética ambiental enrobustece-se e consolida a necessidade de uma "viver" respeitoso no mundo, "incluindo além dos recursos naturais, todos os seres vivos que constituem a fauna, a flora e todos os habitats do planeta” (ROCHA; MONTEIRO, 2017, p. 48).

A transmutação de condutas, culturas e saberes é uma demanda para mitigar o colapso das sociedades (SACHS, 2009), sob risco de tornar-se descartável o princípio da responsabilidade intergeracional. Essa questão permite concluir que a crise ecológica é, sobretudo, uma crise de valores (ROCHA; MONTEIRO, 2017).

Não obstante, impera constatar que o paradigma da sustentabilidade não demanda a interrupção de todo e qualquer abate animal - sobretudo por se tratar de um "caminho do meio". Ao contrário, a essência do desenvolvimento sustentável procura a harmonização das questôes sociais, ambientais e econômicas, de forma a fugir de um fundamentalismo ecológico.

Acerca da questáo que importa à pesquisa - a tratativa animal -, vale invocar os termos da Declaração Universal dos Direitos dos Animais que, apesar de ser 
oficiosa, representa uma tendência jurídica para os planos internacionais e nacionais (TINOCO; CORREIA, 2010). Referida declaração foi proposta por Georges Heuse e consolidou uma tomada de posiçáo filosófica "no sentido de estabelecer diretrizes para o relacionamento do homem com o animal", respaldando a ciência que reconhece a necessidade de percepção de unidade do direito à vida (DIAS, 2017).

Nesse tocante, o artigo $3^{\circ}$, inciso II da Declaração dispóe que a morte de um animal deve ocorrer somente se necessário e, sendo este o caso, sem dor ou angústia (UNESCO, 1978). E mais, os artigos 10, inciso I, 11 e 12, inciso I indicam que os animais não humanos não devem ser empregados para divertimento sob risco de configurar-se biocídio.

Nos termos de Schopenhauer (2005), as indicaçôes da Declaração supra e a inclinação moral pela não morte de animais estáo ligadas à dignidade de caráter. Segundo o pensador, a compaixão pelas "bestas" está também associada à compaixão pelos humanos. "A pessoa que é cruel com relação às criaturas vivas não é um bom homem" (SCHOPENHAUER, 2005).

Essa questão é repetida pelo Papa Francisco, em sua Laudato Si, na medida em que as práticas sustentáveis também incluem um olhar mais fraterno para os "irmáos" animais. Trata-se da encíclica de um "grito profético, que aborda a questão ambiental com mais firmeza e convicção para despertar a responsabilidade universal e a solidariedade planetária" (REIS; BIZAWU, 2015).

A reflexão dos autores acima citados permite concluir que é urgente uma transmutaçáo no que diz respeito à tratativa animal, tendo em vista que as demandas sustentáveis são insustentáveis à visualização das "bestas" enquanto instrumentos para as realizaçóes pessoais e culturais do animal humano (REIS; BIZAWU, 2015).

Impera invocar os ensinamentos de Emmanuel Lévinas (1988), no sentido de que a visão do animal não humano como "Outro" deve ser rompida. Isso porque a sacralidade de todas as vidas coordena outros valores (EINSTEIN, 1955), de forma que a aproximação dos animais - humanos e não humanos - estabelece uma dinâmica mais sustentável. Ou seja, a responsabilização por todos os seres leva à repulsa por qualquer sofrimento desnecessário (LÉVINAS, 1988).

Acompanhando os referidos entendimentos, alguns Estados na Europa já trataram de providenciar legislaçóes que retiram dos animais o caráter de coisas e conferem o status de sujeitos de direitos. Na Alemanha, por exemplo, o artigo $20^{a}$ da Lei Fundamental já dispôs acerca dos animais enquanto seres passíveis de proteção estatal. No mesmo sentido o artigo 90ª do Código Civil alemão expressa que "os animais não são coisas. Eles são protegidos por estatutos especiais" (DEUTSCHLAND, 1896). 
A França também tratou de dispor em seu Código Civil que a senciência animal é bastante para que não sejam as "bestas" submetidas a sofrimento, dor ou morte (FRANCE, 2015). Em sentido similar, a Suíça proíbe a morte, tortura e até mesmo a exposição e a exploração de animais com vertebrados (SUÍÇA, 1978).

Todavia, a análise da utilizaçáo de animais não humanos para realização dos cultos de Candomblé não pode ser pautada única e exclusivamente a partir dos parâmetros éticos e morais ocidentais e judaico-cristáos. Isso porque a cultura africana não é atrelada às perspectivas europeias de construção de pensamento. Sobretudo no caso do Candomblé no Brasil, trata-se do resultado de culturas múltiplas que resultaram em particularidades significativas.

$\mathrm{O}$ que se verifica das informaçóes supra é que o contexto histórico e cultural dos afrodescendentes no Brasil seria bastante para legitimar a realização de sacrifícios de animais não humanos nas cerimônias religiosas - sobretudo se considerarmos que as "bestas" utilizadas para oferenda se resumem a "bodes, cabras, carneiros, porcos, pombos, codornas, patos, frangos, galos e galinhas" (AFLALO, 1996, p. 6).

Trata-se de uma constatação importante, "Na medida em que permite identificar um ethos da comunidade em relação aos animais em questão, e assim impede um tratamento discriminatório em relação a grupos religiosos minoritários que se valem desses mesmos animais em seus rituais de sacrifício" (LEITE, 2013, p. 102).

Ou seja, mesmo dentro da lógica ocidental orientada pelo eixo filosófico europeu, o abate dos animais supra é abarcado pela cultura de consumo de carne. Ora, sendo abatidos centenas de animais diariamente para abastecimento de grande demanda de carne, a restrição do sacrifício de algumas dezenas de "bestas" não alcançaria a utopia absoluta da outridade pretendida.

Fábio Leite (2013) afirma que esse raciocínio foi adotado pela Suprema Corte dos Estados Unidos da América para julgar a inconstitucionalidade do Regulamento 87-71 de Hialeah, na Flórida - que tornava ilegal o sacrifício de qualquer animal em ritual público ou privado enquanto mantinha lícita a caça esportiva, eutanásia de animais sem donos e "o uso de coelhos vivos para treinar cachorros de caça!” (LEITE, 2013, p. 103).

Isso permite dizer que o ânimo dispensado para a discussão acerca da proibição do sacrifício animal em cultos está ligado à discriminação das práticas associadas às religióes de matriz africana (PASSALACQUA, 2010). A própria condicionante geral para o abate - o consumo - carrega um teor segregacionista, na medida em que o "sacrifício nas religióes afro visa inicialmente à oferenda aos orixás, ficando o consumo de carne em segundo plano" (PASSALACQUA, 2010, p. 22). 
Ademais, o sofrimento do animal sacrificado em honra a um orixá é equivalente ao sofrimento do animal sacrificado em um abatedouro, de forma que é inviável a sustentação do argumento que restringe as possibilidades de sacrifício às demandas alimentícias. Ora, não há que se estabelecerem hierarquias nesta questão, se considerarmos que a religião - enquanto manifestação cultural - carrega o peso e os sentidos de um Direito Humano inalienável.

Nesse tocante, importa sopesar os interesses elencados no debate: de um lado, a proteção à identidade cultural e à manifestação religiosa das crenças de matriz africana; de outro, o respeito integral à condição de vida dos animais não humanos, cuja dignidade é a mesma do humano. Assim, é possível dizer que, enquanto náo forem transmutadas as tendências alimentícias voltadas para o consumo de carne - responsável pelo abate de milhóes de animais (no primeiro trimestre de 2018 foram registrados 7,72 milhôes de cabeças abatidas no Brasil) (IBGE, 2018) -, a discussão acerca do sacrifício de animais não humanos nos cultos de Candomblé torna-se frágil e pouco coesa com as realidades sociais.

\section{Consideraçóes finais}

A liberdade religiosa é direito fundamental prescrito na Constituição da República Federativa do Brasil. Assim, é vedada a imposição de credos, bem como sua restrição. Ao contrário, incumbe ao Estado viabilizar a materialização das religiôes no território brasileiro, sob pena de ser ofendido direito de ordem humana. Isso porque, conforme demonstrado, a liberdade de crença e de culto é medida da própria dignidade do homem, enquanto indivíduo e enquanto coletividade.

Não obstante, referido direito é questionado quando suscitado no campo do sacrifício de animais não humanos pelas religiôes de matriz africana - sobretudo o Candomblé. Ora, a comunidade em geral, pautada pela cultura judaico-cristão, tende a projetar a percepção de que os animais são constrangidos quando da realização do abate religioso. Tamanha a extensão da problemática que a discussão foi suscitada na Corte Constitucional, após a tramitação de um projeto de lei no estado do Rio Grande do Sul que vetava a utilização das "bestas" nos rituais de Candomblé, sob a alegação de violação do Código Estadual de proteção aos animais.

O entrave ainda não foi pacificado pelo Supremo Tribunal Federal. Todavia, as discussôes filosóficas e as tendências internacionais a respeito da temática já apontam para um provável resultado. Apesar de ser incontroversa a importância da preservação das espécies e da indispensabilidade de atribuir aos animais não humanos um olhar fundamentado nos princípios da dignidade e no paradigma 
da outridade, as bases da crítica do sacrifício de animais despontam como uma manifestação da rejeição pelos cultos de matriz africana.

Assim, a pesquisa tratou de demonstrar que a cultura de consumo de carne da sociedade brasileira torna pouco coesa a investida pela proibição do abate religioso. Isso porque, o debate parece se preocupar mais com as dezenas de animais sacrificados nos terreiros de Candomblé que com as milhóes de cabeças abatidas de forma comercial. O que se delineia, portanto, é que - antes de se tratar da emancipação da causa animal - a retaliação da prática sacrificial é um instrumento de negação e coerção da cultura negra que, historicamente, é vilipendiada em prol da lógica europeia e judaico-cristã hegemônica.

\section{Referências}

AFLALO, F. Candomblé: uma visão do mundo. 2. ed. São Paulo: Mandarim, 1996.

BARBOSA, D. S. O conceito de orixá no candomblé: a busca do equilíbrio entre os dois universos segundo a tradição iorubana. Sacrilegens, Juiz de Fora, v. 9, n. 1, p. 76-86, jan-jun, 2012.

BERKENBROCK, V. J. A experiência dos Orixás: um estudo sobre a experiência religiosa no candomblé. 3. ed. Petrópolis: Vozes, 2007.

BRASIL. Constituiçâo da República Federativa do Brasil. Brasília, DF: Senado Federal: Centro Gráfico, 1988.

CANOTIlHO, J. J. G. Direito Constitucional e Teoria da Constituição. 6. ed. Coimbra: Almedina, 2002.

COIMBRA, A.; KUO, D. D. Liberdade religiosa: conceitos. São Paulo: Ordem dos Advogados do Brasil, 2009.

D'ADESKY, J. Pluralismo étnico e multi-culturalismo: racismos e anti-racismos no Brasil. Rio de Janeiro: Pallas, 2001.

DARWIN, C. The descente of man, and selection in relation to sex. London: Penguin Books, 2004.

DEUTSCHLAND. Bürgerliches Gesetzbuch (1896). Bürgerliches Gesetzbuch (BGB), 1896.

DIAS, E. C. A evolução da legislação de proteçấo animal e os movimentos sociais na pós-modernidade. In: DIAS, E. C.; SALLES, Á. A (Orgs.). Direito Animal: a 
defesa dos animais sob uma perspectiva ética, histórica e jurídica. Belo Horizonte: 3i, 2017. p. 9-36.

EINSTEIN, A. Como vejo o mundo. Rio de Janeiro: Nova Fronteira, 1955.

FERREIRA, M. F. F. GONÇALVES, J. H. R. A cosmologia do candomblé. Curitiba: Secretaria de Estado da Educação, 2008.

FRANCE. Code Civil ordonnance n. 2015-1288 du 15 octobre 2015. Paris: Organisation Internationale du Travail, 2015.

GROTTANELLI, C. O sacrifício. São Paulo: Paulus, 2008.

HÄBERLE, P. Hermenêutica constitucional: a sociedade aberta dos intérpretes da Constituição: contribuição para interpretação pluralista e "procedimental" da Constituição. Porto Alegre: S. A. Fabris, 2002.

IBGE - INSTITUTO BRASILEIRO DE GEOGRAFIA E ESTATÍSTICA. Estatística de produção pecuária: jan.-mar. 2018. Disponível em: <ftp://ftp.ibge. gov.br/Producao_Pecuaria/Fasciculo_Indicadores_IBGE/abate-leite-couro-ovos_ 201801caderno.pdf>. Acesso em: 03 dez.2018.

LEITE, F. C. A liberdade de crença e o sacrifício de animais em cultos religiosos. Veredas do Direito, Belo Horizonte, v. 10, n. 20, p. 163-177, jul.-dez. 2013.

LÉVINAS, E. Totalidade e infinito. Lisboa: Edições 70, 1988.

MARMELSTEIN, G. Curso de direitos fundamentais. São Paulo: Atlas, 2009.

MIRANDA, J. Manual de Direito Constitucional. 2. ed. Coimbra: Coimbra, 1993.

MIRANDA, J. Manual de direito Constitucional. 3. ed. Coimbra: Coimbra, 2000.

MORAIS, M. E. P. Religião e direitos fundamentais: o princípio da liberdade religiosa no Estado Constitucional Democrático Brasileiro. Revista Brasileira de Direito Constitucional, n. 18, jul.-dez. 2011.

NASCIMENTO, A. A. S. Candomblé e Umbanda: Práticas religiosas da identidade negra no Brasil. RBSE, n. 9, p. 923-944, dezembro, 2010. Disponível em: <http://www.cchla.ufpb.br/grem/AlessandraArt.pdf>. Acesso em: 1 dez. 2018.

ONU - ORGANIZAÇÃO DAS NAÇÓES UNIDAS. Declaração Universal dos Direitos Humanos. 1948. Disponível em: <https://www.unicef.org/brazil/pt/resources_10133.html>. Acesso em: 3 dez. 2018.

PAES, A. C. G. A liberdade religiosa como direito fundamental. Colloquium Humanarum, v. 10, n. especial, jul.-dez. 2013. 
PASSALACQUA, G. P. Apartheid religioso: a Suprema Corte dos EUA e o caso Church of the Lukumi Babalu Aye vs Hialeah City. In: LEITE, F. C (Org.). Cadernos do Departamento de Direito Constitucional. Rio de Janeiro: PUC-Rio, 2010. p. 26-67. (Série Monográfica: Laicidade e liberdade religiosa, v. 1).

PIRES, T. I. T. Liberdade de consciência, liberdade de crença e pluralismo político. Revista do Senado Federal, Brasília, n. 195, v. 49, jul.-set. 2012.

PRANDI, R. Mitologia dos orixás. Sáo Paulo: Companhia das Letras, 2001.

REIS, É. V. B. BIZAWU, K. A encíclica Laudato Si à luz do Direito Internacional do Meio Ambiente. Veredas do Direito, Belo Horizonte, v. 12, n. 23, p. 29-65, jan.-jun. 2015.

RHODEN, H. Mahatma Gandhi. São Paulo: Alvorada, 1982.

RIBEIRO, C. S. G.; CORÇÃO, M. O consumo de carne no Brasil: entre valores socioculturais e nutricionais. Demetra, v. 3, n. 8, p. 428-438, 2013.

ROCHA, M. A.; MONTEIRO, M. S. Consideraçôes acerca dos fundamentos éticos e conceituais dos direitos dos animais. In: DIAS, E. C.; SALLES, Á. A (Orgs.) Direito Animal: a defesa dos animais sob uma perspectiva ética, histórica e jurídica. Belo Horizonte: 3i, 2017. p. 36-60.

ROCHA, S. A. O significado do sacrifício para as religióes de matriz africana: estudos sobre direito dos animais e o princípio constitucional da liberdade religiosa. Revista de Direito da FAT, v. 12, p. 01-26, 2015. Disponível em: <https://saberjuridico.fat.edu.br/publicacoes/edicao12/convidados/Artigo_direitos-animais_Simone_azevedo.pdf>. Acesso em: 1 dez. 2018.

SACHS, I. Desenvolvimento: includente, sustentável, sustentado. Rio de Janeiro: Garamond, 2009. p. 19-26.

SALLES, Á. A. O cuidado com o animal e com o planeta. In: DIAS, E. C.; SALLES, Á. A (Orgs.) Direito Animal: a defesa dos animais sob uma perspectiva ética, histórica e jurídica. Belo Horizonte: 3i, 2017. p. 23-38.

SCHOPENHAUER, A. The basic of morality. 2. ed. New York: Dover, 2005.

SILVA, J. A. Curso de direito constitucional positivo. 5 ed. São Paulo: Revista dos Tribunais, 1989.

STF - SUPREMO TRIBUNAL FEDERAL. RECURSO EXTRAORDINÁRIO: RExt 494.601 RS. Relator: Ministro Marco Aurélio. JusBrasil, 2018a. Disponível 
em: <https://www.jota.info/wp-content/uploads/2018/08/853cb2cd9a2d25be3f92005203fc3923.pdf?x48657>. Acesso em: 1 dez. 2018.

STF - SUPREMO TRIBUNAL FEDERAL. Boletim de Jurisprudência Internacional. 4. Ed. Setembro, 2018b. Disponível em: <http://www.stf.jus.br/arquivo/ $\mathrm{cms} /$ jurisprudenciaInternacional/anexo/BJI4SACRIFCIODEANIMAISEMRITUAISRELIGIOSOS.pdf>. Acesso em: 1 dez. 2018.

SUÍÇA. Ato Federal de Bem-Estar animal, de 09 de agosto de 1978. Cloutier Colection, p. 06-07, 1978.

TINOCO, I. A. P.; CORREIA, M. L. A. Análise crítica sobre a Declaração Universal dos Direitos dos Animais. Revista Brasileira de Direito Animal, Salvador, v. 5, n. 7, p. 169-195, 2010.

UNESCO - ORGANIZAÇĀO DAS NAÇÓES UNIDAS PARA A EDUCAÇÃO, A CIÊNCIA E A CULTURA. Declaração Universal dos Direitos dos Animais, 1978. Disponível em: <http://www.urca.br/ceua/arquivos/Os\%20direitos\%20dos\%20animais\%20UNESCO.pdf>. Acesso em: 29 nov.2018.

UNGER, R. M. O Direito e o futuro da democracia. São Paulo: Boitempo, 2004. 